\title{
PATOLOGI BIROKRASI DAN AGENDA STRATEGI: Kolaborasi Pendekatan New Public Management dan New Public Service Melalui Model Citizen`s Charter
}

\author{
AGUS \\ email: aguschandra.lombok@gmail.com
}

\begin{abstract}
Abstrak
Patologi birokrasi pelayanan publik merupakan keresahan banyak negara, sehingga cara melakukan reformasi birokrasi pelayanan yang efektif. Di era demokrasi, pendekatan tradisional seperti yang berakar pada pemikiran birokrasi weberian sudah dipandang gagal. Dengan tetap menciptakan kompetisi pelayanan melalui metode mewiraswastakan birokrasi sambil tetapi melindungi hak warga negara, tulisan ini berpandangan kolaborasi pendekatan NPM dan NPS merupakan pendekatan baru yang relevan. Pengejawantahan dari kolaborasi kedua pendekatan ini melalui tersedianya dokumen kontrak pelayanan pada setiap instansi Pemerintah yang kemudian dikenal dengan konsep Citizen`s Charter. Tujuan model ini adalah untuk merespon lemahnya posisi tawar masyarakat dalam melakukan kontrol atas proses penyelenggaraan pelayanan publik yang dilakukan oleh birokrasi.
\end{abstract}

Kata Kunci: Patologi, Birokrasi, New Public Management, New Public Service.

\section{A. PENDAhuluan}

Pemerintah memiliki tiga fungsi dasar, yakni pelayanan publik, pembangunan, dan pemberdayaan masyarakat. Pelayanan publik sebagai coore busnnies pemerintah menjadi kajian utama studi administrasi publik. Penyebabnya, karena tugas para administrator publik yakni menyediakan pelayanan kepada publik. Tulisan ini membatasi konsepsi organisasi pemerintah pada birokrasi publik. Kata publik memiliki cakupan luas, meliputi pemerintah, swasta, dan masyarakat. Dengan demikian birokrasi publik merupakan organisasi publik yang bertugas melayani pemerintah, swasta, dan masyarakat.

Konsekuensi pelayanan publik sebagai coore busnnies birokrasi, maka sebagai penyedia layanan, birokrasi dituntut memiliki inovasi agar publik mendapatkan kepuasan dan tidak jenuh dalam menerima layanan. Permasalahannya adalah, 
birokrasi di Indonesia merupakan birokrasi yang miskin inovasi karena dua faktor. Birokrasi di Indonesia tidak memiliki iklim organisasi yang mendorong inovasi, dan para pegawai birokrasi di Indonesia tidak memiliki permasalahan berat apabila bekerja tidak produktif.

Akibat dua faktor di atas, birokrasi menjadi lamban, tidak efisien, kaku, kurang transparan, berbelit-belit, hingga kurang memberi kepastian dalam pelayanan. Tidak sedikit birokrasi di Indonesia justru berperan melayani dirinya sendiri dan megabaikan pelayanan kepada publik. Perilaku korupsi masih mewarnai perilaku birokrasi pelayanan publik. Kondisi birokrasi yang demikian digambarkan sebagai birokrasi yang sakit atau patologis.

Birokrasi sebagai sub-sistem dari sistem sosial, memiliki dinamika seiring dengan dinamikan lingkungan sosialnya. Dengan demikian, perubahan yang terjadi pada lingkungan sosiaal, tidak dapat dihindari menyebabkan pula perubahan manajemen birokrasi pelayanan publik. Tantangan birokrasi kedepan adalah menguatnya perkembangan demokrasi yang mengusung konsep kebebasan, partisipasi, kesetaraan, dan rasionalitas. Perkembangan konsep demokrasi yang demikian memunculkan masyarakat semakin kritis dalam menyikapi pelayanan publik yang mereka terima. Sikap kritis masyarakat yang demikian tidak lagi dijawab oleh pendekatan new public management (NPM) yang mengandalkan penggunaan mekanisme pasar dalam pelayanan publik (2008:74).

Tantangan kedepan kemudian, bagaimana pemerintah sebuah negara membangun administrator publik sebagai pelayan, bukan yang dilayani. Sebagai pelayan, maka administrator publik dituntut memiliki berbagai inovasi, memanfaatkan sumber daya yang yang berkembang di masyarakat, menciptakan regulasi ramah publik, dan menyediakan sumber daya manusia (administrator) yang terbuka dan jujur. Dalam usaha menghadapi tantangan tersebut, diperlukan reformasi manajemen organisasi publik atau birokrasi dengan pendekatan baru. Tulisan ini memandang ada dua pendekatan baru yang relevan yakni, pendekatan new public management (NPM) dan new public service (NPS). Tulisan ini berpandangan bahwa kedua pendekatan tersebut perlu diintegrasikan dalam mewujudkan birokrasi pelayanan yang efisien, efektif, namun saat bersamaan melindungi hak setiap warga negara secara sama. Pengintegrasian kedua pendekatan tersebut, dalam praktiknya memerlukan instrument hukum. Model instrumen hukum yang ditawarkan sebagai solusi adalah konsep customer's charter. 


\section{B. BIROKRASI DAN PELAYANAN PUBLIK}

Birokrasi dan administrasi publik memiliki peran yang signifikan dalam menentukan pelaksanaan tugas-tugas negara. Segera setelah negara membuat keputusan politik, maka peran birokrasi dan administrasi publik menjadi faktor yang menentukan bagaimana keputusan politik itu mampu mencapai tujuannya. Karena perannya yang demikian strategis, ketika tujuan politik suatu negara tidak tercapai, yang dipertanyakan sebagian orang yakni dimana keberadaan administrasi publik, apa yang mereka lakukan. Meskipun demikian, birokrasi dan administrasi publik tidak sepopuler politik dan pengadilan. Ketika negara berhasil mencapai tujuannya sebagian orang memandang bahwa itu merupakan kerja politik. Demikian pula ketika penegakan hukum suatu negara berhasil yang mendapat pujian oleh sebagian orang adalah lembaga peradilan. Birokrasi dan administrasi publik tersembunyi dibalik popularitas politik dan hukum.

Tulisan ini tertarik mengingatkan kembali pikiran akademisi senior ilmu administrasi publik Indonesia Miftah Thoha. Ia mengatakan, usia administrasi dan birokrasi seumur dan setua umur pemerintahan. Ia timbul dalam suatu masyarakat yang terorganisasi. Dalam catatan sejarah peradaban manusia di Asia Selatan, Indonesia, Cina dan Mesir kuno dahulu sudah didapatkan suatau sistem penataan pemerintahan. Sistem penataan pemerintahan tersebut dikenal dengan sebutan administrasi public (2008:87). Dan, hingga saat ini setiap hari orang berurusan dengan administrasi dan birokrasi pemerintahan. Dengan demikian, ruang lingkup pekrjaan administrasi dan birokrasi publik sesungguhnya cukup luas. Mindarti, menyebutnya segala penyelenggaraan atas segenap kepentingan publik dan masalah publik (public interests dan public affairs) yang ada pada suatu negara, merupakan ruang lingkup kegiatan adminisrasi dan birokrasi public (2016:4). Atau dalam bahasa Caiden dan Hainrich, administrasi publik merupakan seluruh kegiatan administrasi untuk segenap urusan publik

Salah satu kegiatan administrasi yang penting bagi publik yakni pelayanan publik. Dengan mengutif pandangan Gronroos, Ratminto dan Winarsih mendefinisikan pelayanan sebagai berikut;

"pelayanan adalah suatu aktivitas atau serangkaian aktivitas yang bersifat tidak kasat mata (tidak dapat diraba) yang terjadi sebagai akibat adanya interaksi antara konsumen dengan karyawan atau hal-hal lain yang 
disediakan oleh perusahaan pemberi layanan yang dimkasudkan untuk memecahkan permasalahan konsumen/pelanggan" (2018:2)

Definisi di atas ingin menjelaskan bahwa ada dua ciri pokok suatu pelayanan, yakni tidak kasat mata dan melibatkan upaya manusia (karyawan) dan peralatan lain yang disediakan oleh perusahaan penyelenggara pelayanan. Pertamyaanya kemudian, bagaimana definisi pelayanan publik?. Menurut Rohman,dkk (2010:3), pelayanan publik adalah pelayanan atau pemberian terhadap masyarakat berupa penggunaan fasilitas umum, baik jasa maupun nonjasa, yang dilakukan oleh organisasi public atau pemerintah. Senada dengan penjelasan tersebut, Sinambela, juga mendefinisikan pelayanan publik sebagai setiap kegiatan yang dilakukan oleh pemerintah terhadap sejumlah manusia yang setiap kegiatan yang menguntungkan dalam kumpulan atau kesatuan, dan menawarkan kepuasan meskipun hasilnya tidak terikat pada suatu produk secara fisik (2006:5).

Dari dua pemikiran di atas, dapat dirumuskan ciri-ciri pelayanan publik yakni; produk layanan itu disediakan oleh pemerintah, bentuk produk adalah fasilitas umum baik jasa maupun nonjasa, peruntukannya adalah untuk publik secara inklusif. Dengan demikian, penyedia pelayanan public adalah pemerintah, dan penerima adalah individu, kelompok orang atau badan hukum, yang memiliki hak dan kewajiban terhadap suatu pelayanan publik.

Secara normatif, undang-undang nomor 25 tahun 2009 tentang pelayanan publik, mendefinisikan pelayanan public sebagai kegiatan atau rangkaian kegiatan dalam rangka pemenuhan kebutuhan pelayanan sesuai dengan peraturan perundang-undangan bagi setiap warga negara, dan penduduk atas barang, jasa dan/atau pelayanan administratif yang disediakan oleh penyelenggara pelayanan publik.

\section{PATOLOGI BIROKRASI PELAYANAN DAN PERMASALAHANNYA}

Mendiskusikan birokrasi di Indonesia selalu identik dengan gambaran birokrasi tidak sehat atau sakit atau patologis. Sebagaimana dikemukan oleh Aris Sunarya, bahwa sudah menjadi rahasia umum berurusan dengan pelayanan publik di Indonesia identik dengan prosedur yang berbelit-belit, tidak ada kepastian waktu, biaya mahal, dan sikap aparat yang tidak ramah kepada warga masyarakat

801 Agus $\begin{array}{r}\text { POLITEA: Jurnal Kajian Politik/slam } \\ \text { Pol. } 2 \text { No. } 1 \text { Januari - Juni } 2019\end{array}$


(2016:445-462). Stigma buruk pelayanan publik seperti ini seakan tidak mengalami perubahan yang berarti bahkan sejak reformasi berjalan. Birokrasi berserta pejabat publik seolah masih memelihara budaya dan mindset kekuasaan, bukannya mengembangkan suatu budaya baru pelayanan kepada warga negara. Penyelenggara pelayanan masih menampakkan wajah sebagai penguasa di hadapan warga, bukannya sebagai penyedia layanan yang selalu mendengar aspirasi warga sebagai pengguna layanan.

Peneliti lain adalah Hamirul, memfokuskan pemabahasannya pada patologi birokrasi yang dimanifestasikan dengan adanya perilaku birokrat yang bersifat disfungsional. Temuan Hamirul pada kasus Pemerintah Kota Cimahi menyebutkan patologi birokrasi disebabkan karena kurangnya atau rendahnya pengetahuan dan keterampilan para petugas pelaksana kegiatan operasional . Jenis ini biasanya dikarenakan keinginan mendapatkan uang lebih. Penyebab lainnya adalah oleh pihak baik masyarakat ataupun birokr:at diantaranya tidak mampu menjabarkan kebijaksanaan pimpinan, rasa puas diri, bertindak tanpa berfikir, kebingungan, sogok, mutu hasil pekerjaan rendah, kedangkalan, ketidaktepatan tindakan, inkompetensi, sikap ragu-ragu, bekerja tidak produktif, ketidakrapian, stagnasi (2017:14-18).

Fred W Riggs menyebutkan patologi birokrasi di negara-negara berkembang terjadi karena intervensi pejabat negara yang seharusnya tidak dilakukan. Intervensi pejabat negera yang berlebihan, menurut Riggs menyebabkan birokrasi gagal melayani kepentingan umum sebagaimana mestinya (1996:306). Fenomena intervensi pejabat negara dalam birokrasi sebagaimana gambaran Riggs nampak semakin jelas di Indonesia, terutama pada birokrasi daerah. Dalam setiap momentum pemilihan gubrnur, bupati/walikota, intervensi calon incumbent terhadap birokrasi cukup massif. Intervensi tersebut tidak berhenti sampai pemungutan suara, namun pasca pemilu berlangsung intervensi masih terus berlangsung.

Persoalannya adalah apakah yang salah dari fenomena birokrasi di Indonesia ?. Tulisan ini menduga permasalahannya terletak pada pendekatan birokrasi yang dibangun tidak sesuai dengan perubahan sosial, ekonomi, politik dan kondisi lokal masyarakat. Indonesia sejatinya masih mempraktekkan pendekatan birokrasi Weberian.

Max Weber mendefinisikan birokrasi sebagai bentuk organisasi dan administrasi di mana kekuasaan organisasi pada umumnya ada di tangan para pejabat yang memiliki keahlian teknis yang diperlukan (dalam Harmon dan Mayer, 
2014:92). Ada tiga unsur utama birokrasi menurut Weber, yakni; (1) aktivitas rutin agen organisasi ditetapkan sebagai tugas resmi; (2) tugas ini relatif stabil dan otoritas untuk melaksanakannya sangat dibatasi secara ketat oleh peraturan, begitu pula kewenangan yang bersifat memaksa tersedia untuk melaksanakannya; (3) ada cara-cara teratur yang sudah ditetapkan untuk menjamin penetapan tugas ini oleh (dan hanya oleh) para individu yang memenuhi aturan umum atau kualifikasi tambahan. Model Weberian tentu sudah tidak tepat digunakan pada masa demokrasi yang cukup dinamis di Indonesia.

Model di atas sering disebut para ilmuan sebagai model birokrasi ideal yang dibangun Weber. Sebaliknya, penulis berpandangan model birokrasi Weberian justru telah menyebabkan bangunan birokrasi menjadi kaku, lamban, formalistis, berorientasi pada proses dan aturan bukan pada hasil. Jika model birokrasi Weberian dipertahankan, maka publik akan lebih memilih organisasi privat sebagai tempat untuk memenuhi urusan-urusan mereka.

B.3.. Reformasi Birokrasi Pelayanan

Reformasi birokrasi sudah dilakukan banyak negara sebagai kebutuhan untuk menjawab tuntutan publik yag terus berkembang. Studi yang dilakukan oleh Cheung, Anthony B.L misalnya menyebutkan, di Hongkong reformasi birokrasi telah dilakukan sejak tahun 1980-an, persisnya diumumkan oleh pemerintah Hongkong tahun 1989. Aspek-aspek yang mendapatkan perhatian reformasi birokrasi di Hongkong meliputi dua komponen. Pertama, redefinisi kekuasaan dan akuntabilitas hubungan antara lembaga-lembaga eksekutif di pusat. Kedua, manajemen sumber daya manusia yang lebih berorientasi bisnis dan konsumen dalam pengelolaan layanan publik. Pendekatan yang digunakan dalam reformasi birokrasi di Hong Kong adalah new public management (NPM). Dan nampaknya Cheung, Anthony B.L merupakan penggemar dari NPM.

Argumen karya Cheung Anthony B.L menyebutkan bahwa berbagai bentuk manajemen layanan publik tujuannya adalah untuk mencari pemberdayaan birokrasi pelayanan publik. Model birokrasi Weberian dianggap telah gagal atau sulit untuk dipertahankan. Maka NPM memberikan mode pemberdayaan baru, berdasarkan kebebasan manajerial, otonomi, dan pendekatan pasar. Oleh Cheung, Anthony B.L pendekatan NPM di pandang akan memunculkan kelahiran kembali kekuasaan birokrasi di bawah manajerialis. Hasil studi Cheung menemukan di Hong Kong pendekatan NPM mampu menghasilkan reformasi birokrasi dengan lebih baik karena terjadi dalam lingkungan yang tidak menghadapi masalah serius 
pada krisis ekonomi, fiskal, atau pemerintahan (1996:37-50). Poin penting dari analisa Cheung adalah praktik NPM akan berhasil manakala kondisi negara sehat, artinya tidak mengalami masalah krisis ekonomi dan pemerintahan.

Selain kondisi ekonomi dan pemerintahan suatau negara, penerapan pendekatan NPM dalam usaha mereformasi birokrasi pelayanan publik, sebaiknya memperhitungkan variabel lokalitas suatu negara. Studi yang dilakukan oleh Nissim Chohen dari Universitas Haifa mengingatkan kita dengan mengatakan bahwa reformasi administrasi membutuhkan pendekatan sistematis dan memperhitungkan banyak faktor. Para perancang reformasi birokrasi harus memperhatikan konteks sosial atau konteks lokal. Chohen menambahkan meskipun pendekatan NPM sukses di negara-negara maju sejak tahun 1980-an dan 1990-an, namun belum tentu berlaku di sistem lain seperti di negara-negara berkembang (2016).

Kajian pelayanan publik di Indonesia juga telah banyak dilakukan para ahli. Penelitian Rachmawati dan Nasutian tentang nilai demokrasi dalam pelayanan publik di kantor Imigrasi Bandung, menemukan bahwa Kantor Imigrasi Bandung yang merupakan salah satu contoh terbaik (best practice) dalam praktik pelayanan publik. Namun demikian, kantor Imigrasi Bandung masih belum menerapkan nilai integritas dengan baik. Hal tersebut ditunjukkan oleh dua hal yaitu (1) adanya penyalahgunaan fasilitas kantor (kendaraan dan ATK) untuk keperluan pribadi; dan (2) keberadaan biro jasa yang dapat memunculkan perilaku tidak objektif dari penyelenggara pelayanan publik di kantor Imigrasi Bandung (2015:133).

Dari dua penelitian di atas, dapat dipetik catatan penerapan pendekatan NPM sebagai epistimologi reformasi birokrasi menuju pencegahan patologi birokrasi, yakni kondisi suatu negara yang mencakup kondisi ekonomi dan pemerintahan. Kemudian kondisi masyarakat yang mencakup nilai-niali lokalitas yang berkembang di masyarakat.

\section{AGENDA STRATEGI: KOLABORASI PENDEKATAN NPM DAN NPS}

Dari temuan diskusi di atas, dapat disusun posisi akademik tulisan ini sebagai berikut. Secara ontologis, reformasi manajemen organisasi merupakan suatu kebutuhan untuk mengobati patologi birokrasi di Indonesia. Epistimologi atau metode pelaksanaannya mengganti pendekatan Weberian menjadi new public management (NPM) tapi sekaligus memasukkan nilai-nilai new public service (NPS). Cara memasukkan nilai-nilai NPS pada praktik NPM yakni melalui good 
governance, yang meliputi transparansi, demokrasi, kepastian hokum, efisiensi, efektivitas, dan akuntabilitas. Melalui kolaborasi model pendekatan ini diharapkan patologi birokrasi yang selama ini sudah akut menjadi sehat dan mampu menghadirkan pelayanan publik yang memiliki nilai keadilan, persamaan hak dan kewajiban warga negara, dan kesetaraan.

Perkembangan pendekatan studi administratsi publik telah mengalami empat tahapan perkembangan, yakni Old Public Administration (OLP), New Public Management (NPM), New Public Service (NPS), dan Governance. Sebagai pendekatan analisis dan metodologis, kehadiran salah satu pendekatan tersebut tidak bersifat menghilangkan keberlakuan pendekatan sebelumnya. Oleh karena itu, penulis berpandangan mengkolaborasikan pendekatan NPM dan NPS sebagai jalan revilatisasi untuk menyembuhkan patologi birokrasi pelayanan publik dibenarkan secara ilmu pengetahuan. Pendekatan NPM yang muncul tahun 1980an digagas untuk memperbaiki kinerja administrasi publik yang lamban dalam memberikan pelayanan publik, dengan cara memasukkan prinsip kewirausahaan seperti yang berlaku di organisasi privat. Berusaha memberi sentuhan kompetisi untuk menghasilkan efektivitas, efisiensi dan produktifitas yang tinggi dalam organisasi publik. Deddy Mulyadi menguraikan enam konsep inti untuk memahami pendekatan NPM, sebagai berikut (2016:223);

1. Pemerintah diajak untuk meninggalkan paradigma administrasi tradisional dan menggantikannya dengan perhatian terhadap kinerja atau hasil kinerja

2. Pemerintah sebaiknya melepaskan diri dari birokrasi klasik dan membuat situasi dan kondisi organisasi, pegawai dan para pekerja lebih fleksibel

3. Menetapkan tujuan dan target organisasi dan personel lebih jelas sehingga memungkinkan pengukuran hasil melalui indikator yang jelas

4. Staf senior lebih berkomitmen secara politis dengan pemerintah seharihari daripada netral

5. Fungsi pemerintah adalah memperhatikan pasar, kontrak kerja keluar, yang berarti pemberian pelayanan tidak selamanya melalui birokrasi, melainkan bisa diberikan oleh sector swasta 


\section{Fungsi pemerintah dikurangi melalui privatisasi}

Negara-negara yang dipandang sukses menerapkan pendekatan NPM, yakni Amerika, Inggris dan Selandia Baru. Meskipun Indonesia pernah menerapkan pendekatan ini pada masa pemerintahan Meawati dengan cara melakukan privatisasi besar-besaran, namun menurut Mulyadi Indonesia tidak sesukses negara-negara di atas. Menurut Mulyadi, penyebab kegagalan privatisasi, sebut saja contohnya adalah Indosat, karena privatisasi tersebut dilakukan tanpa pemahaman yang tepat tentang bagaimana predeksi kedepannya. Selain itu, memang ada kendala konstitusional. Misalnya konstitusi di Indonesia menyebutkan, semua masyarakat berhak mendapatkan perlakuan yang sama dari negara. Sebagai ilustrasi, tidak boleh ada pembedaan hanya karena perbedaan sejumlah uang yang dibayarkan kepada pemberi pelayanan publik. NPM cenderung menyebabkan pelayanan publik berbiaya mahal, sehingga tidak mampu dinimati oleh seluruh warga negar.

Berbeda dengan NPM, maka NPS merupakan pendekatan yang menekankan berbagai elemen. Ada empat ide dasar yang melahirkan pendekatan NPM, yakni: teori democratic citizenship; model komunitas dan civil society; organisasi humanism; dan post modern ilmu administrasi publik. Akhir-akhr ini konsep democratic dan citizenship meupakan isu yang cukup penting. Citizenship merupakan konsep yang menjelaskan tentang kewarganegaraan, yang diartikan sebagai hak dan kewajiban, sebagaimana yang ditetapkan atau diatur oleh peraturan perundang-undangan. Secara luas, diartikan sebagai isu-isu umum atas keterlibatan seseorang ke dalam keanggotaan komunitas politik, termasuk isu mengenai hak dan kewajiban selain yang diatur dalam perundang-undangan yang berlaku. Dengan demikian, warga negara berkaitan dengan seseorang individu yang mempunyai kebebasan untuk terlibat dalam keanggotaan komunitas dan kehidupan politik dan mempengaruhi sistem politik yang ada.

Pemahan dasar tentang konsep warga negara di atas, menjadi dasar untuk memahami citizenship democratic. Konsep ini menegaskan bahwa negara atau pemerintahan dan hubungan warga negara dan negara dalam basis bahwa pemerintah itu diperlukan untuk menjamin warga negaranya bisa membuat pilihan-pilihan yang bebas selaras dengan kepentingan individu yang dijamin dengan suatu prosedur dan hak individu. 
Dengan demikian, jika pendekatan NPM membatasi peran atau campur tangan pemerintah dalam pelayanan publik, maka NPS mengharapkan campur tangan pemerintah itu masih penting. Tapi NPS mengingatkan campur tangan pemerintah dalam rangka melindungi hak warga negara dalam pelayanan publik. Artinya tulisan ini mengambil posisi pendekatan NPM melalui model mewiraswastakan birokrasi pada pelayanan publik tidak bermasalah, sepanjang negara juga hadir untuk melindungi hak warga negara. Bentuk kehadiran negara yang dimaksud melalui penyediaan regulasi dan pengawasan.

\section{E. CITIZEN`S CHARTER SEBAGAI SOLUSI}

Pertanyaan yang muncul setelah diskusi tentang integrasi pendekatan NPM dan NPS dalam mereformasi birokrasi pelayanan publik adalah bagaimana praksisnya?. Untuk menjawab kegelisahan ini penulis terinspirasi dari makalah yang ditulis oleh Wahyudi Kumorotomo dengan judul Citizen Charter (Kntrak Pelayanan): Pola Kemitraan Strategis Untuk Mewujudkan Good Governance Dalam Pelayanan Publik (2007:6).

Sebagai pendekatan baru, Citizen`s Charter atau sering dikenal dengan Customer`s Charter, belum terlalu akrab di Indonesia. Menurut Ratminto dan Winarsih (2018:305), konsep ini pertamakali diperkenalkan di Inggris pada masa Perdana Menteri Margareth Thatcher. Pada awalnya merupakan sutu dokumen yang didalamnya disebutkan hak-hak dan kewajiban-kewajiban yang melekat baik dalam diri providers maupun dalam diri customers. Kemudian dalam perkembangannya, dalam dokumen tersebut disebutkan juga sanksi-sanksi apabila salah satu pihak tidak dapat memenuhi kewajibannya. Perkembangan berikutnya, di dalam dokumen tersebut juga disebutkan visi dan misi organisasi penyelenggara jasa pelayanan.

Di Malayasia, menurut catatan Ratminto dan Winarsih, program Citizen`s Charter telah dikembangkan oleh the Malaysian Administrative Modernization and Management Planning Unit (MAMPU), sehingga setiap instansi Pemerintah wajib membuat Citizen`s Charter. Di Malaysia, Citizen`s Charter ini diartikan sebagai suatu komitmen tertulis yang berkaitan dengan penyelenggaraan pelayanan yang ditujukan kepada pengguna jasa pelayanan instansi Pemerintah tertentu. Dengan demikian Citizen`s Charter adalah jaminan yang diberikan oleh instansi Pemerintah kepada pengguna jasanya, bahwa pelayanan yang dikelolanya standard yang sesuai dengan harapan dari pengguna jasa. Apabila standard yang tertera dalam dokumen Citizen`s Charter tidak dapat dipenuhi, maka masyarakat selaku 
pengguna jasa pelayanan dapat mempergunakan Citizen`s Charter yang telah dirumuskan sebagai alat untuk memprotes atau menuntut instansi Pemerintah yang gagal memenuhi standard pelayanan sebagaimana dituliskan dalam dokumen Citizen`s Charter.

Di dalam praktek, 'kontrak pelayanan' digunakan untuk mendorong penyedia layanan, pengguna layanan dan stakeholders (pemangku kepentingan, pemegang kunci) lainnya untuk membuat "kesepakatan bersama" tentang jenis, prosedur, biaya, waktu \& cara memberikan pelayanan. Tujuan dari terbentuknya Kontrak Pelayanan memang untuk membuat agar pelayanan publik menjadi lebih tanggap atau responsif, transparan dan bertanggungjawab atau akuntabel. Maka perumusan Kontrak Pelayanan itu harus melibatkan para pengguna layanan, seluruh satuan yang terlibat dalam penyediaan layanan, LSM, DPRD, tokoh masyarakat lokal, dan lain-lainnya.

Selanjutnya, Trantoro menjelaskan latar belakang kemunculan pendekatan citizen charter untuk mersepon lemahnya posisi tawar masyarakat dalam melakukan kontrol atas proses penyelenggaraan pelayanan publik yang dilakukan oleh birokrasi. Pendekatan ini memposisikan kepentingan pengguna layanan sebagai pusat perhatian. Artinya kebutuhan dan kepentingan pengguna layanan sebagai pertimbangan utama dalam proses penyelenggaraan pelayanan publik (2004:33-40).

\section{F. KESIMPULAN}

Patologi birokrasi pelayanan publik merupakan keresahan banyak negara, sehingga cara melakukan reformasi birokrasi pelayanan yang efektif. Di era demokrasi, pendekatan tradisional seperti yang berakar pada pemikiran birokrasi weberian sudah dipandang gagal. Dengan tetap menciptakan kompetisi pelayanan melalui metode mewiraswastakan birokrasi sambil tetapi melindungi hak warga negara, tulisan ini berpandangan kolaborasi pendekatan NPM dan NPS merupakan pendekatan baru yang relevan. Pengejawantahan dari kolaborasi kedua pendekatan ini melalui tersedianya dokumen kontrak pelayanan pada setiap instansi Pemerintah yang kemudian dikenal dengan konsep Citizen`s Charter. Tujuan model ini adalah untuk merespon lemahnya posisi tawar masyarakat dalam melakukan kontrol atas proses penyelenggaraan pelayanan publik yang dilakukan oleh birokrasi. 


\section{DAFTAR PUSTAKA}

B.L.,Cheung, Anthony, 1996, Public sector reform and the re-legitimation of public bureaucratic power The case of Hong Kong The International Journal of Public Sector Management ;Bradford Vol.9. Iss.5.6 (1996):37-50

Chohen, Nissim, 2016, Forgoing, New Public Management and Adopting PostNew Public Management Principles: The on-going Civil Service Reform Israel, (Public Admin. Dev. 36,20-34 (2016) Published online in Wiley Online Library (wileyonlinelibrary.com) DOI: 10.1002/pad.1751

Caiden, Gerald E. \& Hainrich Seidentopl, Strategies for Administrative Reform, Lexington Bocks: Massachussets-Toronto

Hamirul, 2017, Patologi Birokrasi Yang Dimanifestasikan Dalam Perilaku Birokrat Yang Bersifat Disfungsional (Otoritas: Jurnal Ilmu Pemerintahan 7 (1), April 2017, hlm.14-18

Hamon, Michael M. dan Richard T.Mayer, 2014, Teori Organisasi Untuk Administrasi Publik, judul aslinya Organization Theory of Public Administrasion, diterjemahkan oleh Saut Pasaribu, Bantul, Kreasi Wacana

Mindarti, Lely Indah, 2016 Aneka Pendekatan dan Teori Dasar Administrasi Publik, Malang, UB Press

Mulyadi, Deddy, 2016, Studi Kebijakan Publik dan Pelayanan Publik Konsep dan Aplikasi Proses Kebijakan Publik Berbasis Analisis Bukti untuk Pelayanan Publik, Bandung, Alfabeta

Rachmawati, Tutik \& Sunia, 2015, Julian Nasution, Nilai Demokrasi dalam Pelayanan Publik: Studi Kasus Kantor Imigrasi Bandung, Jurnal Kebijakan Publik, Vol.19, No. 2 November 2015,

Ratminto \& Atik Septi Winarsih, 2018, Manajemen Pelayanan Pengembangan Model Konseptual, Penerapan Citizen`s Charter dan Standar Pelayanan Minimum, Yogyakarta, Pustaka Pelajar

Riggs, Fred W, 1996, Administrasi Negara-negara Berkembang Teori Masyarakat Transisi, jdudl aslinya Administration in developing countries, diterjemahkan ke dalam bahasa Indonesia oleh Tim Penerjamaah Yosagama (Jakarta, PT.RajaGrafindo Persada, 1996), hlm.306 
Rohman, Ahmad Ainur, dkk, 2010, Reformasi Pelayanan Publik, Malang, Program Sekolah Demokrasi

Sunarya, Aris, 2016, Reformasi Birokrasi Administrasi Pelayanan Pajak Kendaraan Brmotor Berbasis Mobile Technology di Kantor Bersama Samsat Jawa Timur (JPAP: Jurnal Penelitian Administrasi Publik, Oktober 2016, Vol 2.No.2. hlm.445-462

Thoha,Miftah, 2008, Ilmu Administrasi Publik Kontemporer, Jakarta, Prenada Media Group,

Triantoro, Bambang Wicaksono, Citizen Charter dan Reformasi Birokrasi, Jurnal Kebijakan dan Administrasi Publik, Vol.8 No.2, November 2004, hlm. 33-40 
